\title{
OBSERVASI SEBAGAI ALAT EVALUASI DALAM DUNIA PENDIDIKAN DAN PENGAJARAN
}

\begin{abstract}
Oleh: Sitti Mania*
ABSTRACT: Evaluation is one of the key factors in the field of education, particularly in the process of teaching, due to its function to assess the extent to which the development of students. In practice, evaluation may be done by using test and non-test technique. Observation, the central issue of this paper, is classified as non-test technique. It is an instrument of collecting data by a systematic process of surveillance and note taking on the behavior of students, both individually and collectively. Additionally, observation is considered the most relevant evaluation instrument to access the affective and psychomotor domain of students. One may implement participative, non-participative, and quasi observation. The quality of this instrument is judged based on its validity, which strongly due to the skill, knowledge, and attitude of the observer.
\end{abstract}

KEYWORDS: Observasi, observer, observee

EVALUASI ${ }^{1}$ dalam arti luas mengandung pengertian sebagai suatu proses merencanakan, memperoleh dan menyediakan informasi yang sangat diperlukan untuk membuat alternatif-alternatif keputusan. ${ }^{2}$ Berdasarkan definisi tersebut, maka setiap kegiatan evaluasi merupakan suatu proses yang sengaja direncanakan dengan tujuan untuk memperoleh informasi atau data, dan berdasarkan data tersebut kemudian dibuat satu keputusan.

Evaluasi dalam hubungannya dengan kegiatan pengajaran adalah suatu proses yang sistematis untuk menentukan atau membuat keputusan sampai sejauhmana tujuan-tujuan pengajaran telah dicapai oleh siswa. ${ }^{3}$ Evaluasi pendidikan dan pengajaran juga mengandung arti penaksiran terhadap pertumbuhan dan kemajuan siswa ke arah tujuan-tujuan atau nilai-nilai yang telah ditetapkan di dalam kurikulum. ${ }^{4}$

Berdasarkan beberapa definisi di atas, ada tiga aspek yang perlu diperhatikan untuk lebih memahami apa yang dimaksud dengan evaluasi pengajaran. Pertama, kegiatan evaluasi merupakan proses yang sistematis.

*Magister dalam bidang Pemikiran Pendidikan ini adalah lulusan Program Pascasarjana UIN Sunan Kalijaga, Yogyakarta. Saat ini ia sebagai dosen tetap Fakultas Tarbiyah dan Keguruan UIN Alauddin Makassar. 
Hal ini mengandung arti bahwa evaluasi merupakan kegiatan yang terencana dan dilakukan secara berkesinambungan. Kedua, dalam kegiatan evaluasi diperlukan berbagai informasi atau data yang menyangkut obyek yang sedang dievaluasi. Data yang dimaksud bisa berupa hasil ulangan atau tugas-tugas pekerjaan rumah, nilai midsemester, nilai ujian akhir semester, ataupun berupa perilaku dan penampilan siswa selama mengikuti pelajaran. Berdasarkan data-data tersebut, kemudian diambil suatu keputusan berdasarkan tujuan dan maksud evaluasi yang sedang dilakukan. Ketiga, setiap kegiatan evaluasi dalam dunia pendidikan dan pengajaran tidak dapat dilepaskan dari tujuan-tujuan pengajaran yang hendak dicapai. Hal tersebut dikarenakan setiap kegiatan evaluasi memerlukan suatu kriteria tertentu sebagai acuan dalam menentukan batas ketercapaian objek yang dinilai.

Ketiga hal yang dipaparkan di atas menjadikan observasi-sebagai salah satu model dari teknik non tes-sangat menarik untuk dibahas.

\section{OBSERVASI DALAM PENGERTIAN UMUM}

Secara umum, observasi merupakan cara atau metode menghimpun keterangan atau data yang dilakukan dengan mengadakan pengamatan dan pencatatan secara sistematis terhadap fenomena yang sedang dijadikan sasaran pengamatan.

Dengan kata lain, observasi dilakukan untuk memperoleh informasi tentang kelakuan observee yang sebenarnya. Dengan demikian, melalui kegiatan observasi dapat diperoleh gambaran yang lebih jelas tentang kehidupan sosial yang sukar diperoleh dengan menggunakan metode lain. Observasi sangat diperlukan jika observer belum memiliki banyak keterangan tentang masalah yang diselidikinya. Sehingga observer dapat memperoleh gambaran yang jelas tentang masalahnya serta petunjukpetunjuk cara memecahkannya.

Sehubungan dengan fungsinya sebagai pengumpul data, maka observasi harus dilakukan secara sistematis dan terarah, bukan dengan secara kebetulan saja. Dalam hal ini, observasi serta pencatatannya sedapat mungkin dilakukan menurut prosedur dan aturan-aturan tertentu sehingga hasil observasi memberi kemungkinan untuk ditafsirkan secara ilmiah. Lebih jauh dikatakan, kegiatan observasi diusahakan mengamati keadaan yang wajar dan yang sebenarnya tanpa ada usaha yang disengaja untuk mempengaruhi, mengatur, dan memanipulasi situasi dan kondisi yang sedang diamati. $^{5}$

Pentingnya mengadakan observasi secara sistematis dan terarah dikarenakan oleh kegiatan observasi yang sesuai dengan kenyataan, 
melukiskannya dengan kata-kata yang cermat dan tepat tentang apa yang diamati, mencatatnya dan kemudian mengolahnya secara ilmiah bukanlah pekerjaaan mudah. Hal tersebut dikarenakan apakah hasil pengamatan tersebut sudah valid dan reliabel, dan apakah obyek pengamatan tersebut representatif bagi gejala yang sama.

Terdapat banyak jenis situasi sosial yang dapat diselidiki dengan observasi, mencakup bermacam penelitian mengenai tingkah laku fisik, sosial, dan emosional, dari murid TK, SD, Sekolah Menengah sampai kepada pengamatan terhadap tingkah laku orang dewasa, di pabrik, di kantor, di rumah, dalam kelompok diskusi, dan dalam situasi-situasi lain di masyarakat.

\section{JENIS PENGAMATAN}

Dalam garis besarnya, observasi dapat dilakukan: 1) dengan partisipasi pengamat, 2) tanpa partisipasi pengamat ${ }^{6}$, dan 3) quasi partisipasi. ${ }^{7}$

Pada observasi partisipasi, peneliti melibatkan diri di tengah-tengah kegiatan obyek yang sedang diteliti. Hal ini mengandung arti bahwa peneliti harus ikut serta dalam kegiatan yang dilakukan oleh individu atau kelompok yang ditelitinya. Jika seorang peneliti ingin meneliti di sebuah perusahaan, peneliti tersebut menjadi pekerja dalam perusahaan yang akan diselidikinya.

Dalam observasi partisipasi, peneliti menjadi bagian integral dari situasi yang ditelitinya, peneliti terlibat langsung sehingga dapat lebih menghayati, merasakan serta mengalami sendiri seperti apa yang dialami oleh obyek penelitiannya, karena kehadirannya tidak mempengaruhi situasi yang sebenarnya. Dengan demikian, hasil pengamatan akan lebih berarti dan lebih objektif, sebab dapat dilaporkan sebagaimana apa adanya sesuai dengan kenyataan. Namun, di sisi lain, metode ini sering mengandung suatu kelemahan. Kelemahan tersebut ada dalam diri peneliti itu sendiri. Artinya, terkadang peneliti kurang cermat dan kurang konsentrasi sehingga hasil pengamatannya lebih banyak dipengaruhi oleh pendapatnya sendiri, bukan oleh perilaku objek yang sedang diamatinya. ${ }^{8}$ Kelemahan lain, karena peneliti terlibat langsung dalam kegiatan obyek yang ditelitinya, maka besar kemungkinan ia tidak dapat lagi melihat dan "membaca" secara tajam hal-hal yang khas yang harus diamati dan dicatat, karena baginya hal-hal tersebut sudah tidak khas lagi. Untuk meminimalkan kelemahan tersebut, observasi sebaiknya dilakukan oleh dua orang atau lebih secara terpisah terhadap satu obyek. Kemudian hasilnya dibandingkan dan dicocokkan untuk menentukan hasil akhir pengamatan dari semua pengamat. ${ }^{9}$ 
Sedangkan pada observasi nonpartisipasi, peneliti berada "di luar garis" dari kegiatan obyek observasi, misalnya peneliti mengobservasi para pekerja tanpa menjadi pekerja dalam perusahaan itu. Observasi jenis ini banyak dipergunakan oleh para peneliti karena banyaknya kesulitan yang ditemui ketika menggunakan metode observasi partisipasi. ${ }^{10}$ Namun, kelemahannya terkadang kehadiran peneliti dapat mempengaruhi kelakuan atau perilaku obyek yang ditelitinya, atau dengan kata lain, situasi sudah tidak sewajarnya lagi. Untuk mengurangi kelemahan tersebut, peneliti harus sanggup menyesuaikan diri dalam situasi tersebut dan jangan terlalu menonjol, agar tidak mempengaruhi kewajaran kelakuan orang yang diamatinya. Di samping itu, peneliti dapat mengadakan pengamatan dengan cara menyamar, sehingga kehadirannya-sebagai seorang peneliti-tidak disadari observee.

Pada observasi quasi partisipasi, observer melibatkan diri pada saatsaat tertentu, dan pada saat-saat lain observer berada di luar situasi yang sedang ditelitinya.

\section{OBSERVASI DALAM DUNIA PENDIDIKAN DAN PENGAJARAN}

Sebelum membahas lebih jauh tentang observasi dalam dunia pendidikan dan pengajaran, terlebih dahulu akan dikemukakan tiga situasi yang dapat diselidiki melalui observasi. Ketiga macam situasi yang dimaksud adalah:

Pertama, situasi bebas (free situation). Pada situasi bebas, observee berada dalam keadaan bebas, tidak terganggu bahkan tidak mengetahui bahwa mereka sedang diamati. Dengan observasi terhadap situasi bebas, observer dapat memperoleh data yang sewajarnya tentang peristiwa atau tingkah laku seseorang atau kelompok. ${ }^{11}$

Kedua, situasi yang dibuat (manipulated situation). Pada situasi yang seperti ini, observer sengaja membuat atau menambahkan kondisi-kondisi atau situasi-situasi tertentu, kemudian mengamati bagaimana reaksi-reaksi yang timbul dengan adanya kondisi atau situasi yang sengaja dibuat itu. ${ }^{12}$ Anas Sudijono menegaskan bahwa observasi pada situasi yang seperti ini, memerlukan perencanaan dan persiapan yang matang. ${ }^{13}$ Observasi yang dilakukan terhadap kegiatan-kegiatan belajar yang sifatnyaketerampilan termasuk ke dalam jenis situasi yang dibuat.

Ketiga, situasi campuran (partially controlled). Situasi campuran adalah situasi dalam observasi yang merupakan gabungan dari kedua macam situasi tersebut di atas.

Observasi fungsinya sebagai alat evaluasi dalam dunia pendidikan dan pengajaran banyak digunakan untuk menilai kegiatan-kegiatan belajar 
yang bersifat keterampilan, ${ }^{14}$ ataupun proses terjadinya suatu kegiatan yang dapat diamati, baik dalam situasi bebas maupun dalam situasi buatan. ${ }^{15}$ Dengan kata lain, observasi dipergunakan untuk mengukur dan menilai hasil dan proses belajar, seperti, tingkah laku siswa pada waktu mengikuti kegiatan belajar, bagaimana cara siswa mengelas, menjahit pakaian, mengetik, menyambung kabel dan memasang alat-alat listrik, tingkah laku siswa pada jam-jam istirahat atau pada saat terjadinya kekosongan pelajaran, tingkah laku siswa ketika mengikuti upacara bendera, kegiatan diskusi siswa, partisipasi siswa dalam simulasi dan sebagainya.

Dengan demikian, melalui observasi dapat diketahui bagaimana sikap dan perilaku siswa, kegiatan yang dilakukannya, tingkat partisipasi dalam suatu kegiatan, proses kegiatan yang dilakukannya, begitu pula deskripsi objektif dari individu-individu dalam hubungannya yang aktual satu sama lain dan hubungan mereka dengan lingkungannya dapat diperoleh. Dalam hal ini observasi harus dilakukan pada saat proses kegiatan tersebut berlangsung, dan guru tidak perlu terlalu formal memperhatikan tingkah laku siswa, tapi ia cukup mencatat secara teratur gejala dan tingkah laku yang ditunjukkan oleh setiap siswa. Dengan mencatat tingkah laku dan ekspresi mereka yang timbul secara wajar, teknik observasi menjamin proses pengukuran dan evaluasi itu tanpa merusak atau mengganggu kegiatan-kegiatan normal dari kelompok atau individu yang diamati.

\section{Rancangan Instrumen Observasi}

Agar pelaksanaan observasi dapat berlangsung efektif dan efisien maka observer perlu membuat rancangan instrumen observasi yang memuat hal-hal apa saja yang menjadi obyek pengamatannya. Dalam membuat instrumen observasi ada beberapa langkah yang dapat ditempuh. 1) terlebih dahulu lakukan observasi langsung terhadap suatu proses tingkah laku, kemudian catat kegiatan yang dilakukannya, selanjutnya tentukan jenis perilaku-perilaku tertentu yang akan diamati nanti. 2) urutkan jenis perilaku-perilaku tersebut sesuai dengan apa yang seharusnya. Rumusan tingkah laku tersebut harus jelas dan spesifik sehingga dapat diamati. 3) tentukan bentuk instrumen observasi, apakah bentuk bebas-mencatat apa saja yang tampak-atau pedoman yang berstruktur. 4) terlebih dahulu, diskusikan instrumen observasi tersebut dengan calon observer lain agar setiap segi yang akan diamati dapat dipahami maknanya dan bagaimana cara mengisinya. 5) sebaiknya disediakan catatan khusus atau komentar observer pada bagian akhir 
pedoman observasi untuk mencatat hal-hal menarik yang tidak tercantum dalam pedoman observasi tersebut. ${ }^{16}$

Dalam tulisan ini, penulis mengemukakan tiga contoh instrumen observasi. Contoh instrumen yang pertama dan kedua, menggunakan anecdotal record, 17 sedang contoh instrumen yang ketiga adalah bentuk bebas, tanpa menentukan terlebih dahulu aspek-aspek serta tingkah laku yang akan diamati.

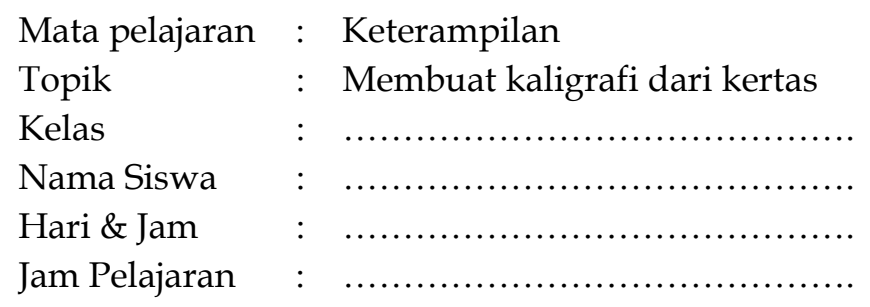

\begin{tabular}{|r|l|l|l|}
\hline No. & \multicolumn{1}{|c|}{ Kegiatan/Aspek yang Dinilai } & Skor/Nilai & Ket. \\
\hline 1. & Persiapan alat-alat (bahan) & & \\
2. & Kombinasi bahan & & \\
3. & Kombinasi warna & & \\
4. & Cara mengerjakan & & \\
5. & Sikap waktu mengerjakan & & \\
6. & Ketepatan waktu mengerjakan & & \\
7. & Kecekatan & & \\
8. & Hasil pekerjaan & & \\
\hline
\end{tabular}




\section{Pedoman Observasi}

Nama Siswa

Kelas

\begin{tabular}{|c|c|c|c|c|c|}
\hline No. & $\begin{array}{c}\text { Kegiatan/Aspek yang } \\
\text { Dinilai }\end{array}$ & Tinggi & sedang & Kurang & Ket. \\
\hline 1. & $\begin{array}{l}\text { Memberikan pendapat } \\
\text { untuk pemecahan masa- } \\
\text { lah }\end{array}$ & & & & \\
\hline 2. & $\begin{array}{l}\text { Memberikan tanggapan } \\
\text { terhadap pendapat orang } \\
\text { lain. }\end{array}$ & & & & \\
\hline 3. & $\begin{array}{l}\text { Mengerjakan tugas yang } \\
\text { diberikan. }\end{array}$ & & & & \\
\hline 4. & $\begin{array}{l}\text { Motivasi dalam } \\
\text { mengerjakan tugas-tugas. }\end{array}$ & & & & \\
\hline 5. & $\begin{array}{l}\text { Toleransi dan mau } \\
\text { menerima pendapat } \\
\text { siswa lain. }\end{array}$ & & & & \\
\hline 6. & $\begin{array}{l}\text { Tanggung jawab sebagai } \\
\text { anggota kelompok. }\end{array}$ & & & & \\
\hline 7. & Dan seterusnya... & & & & \\
\hline & Jumlah Skor & & & & \\
\hline
\end{tabular}

Catatan tambahan dari observer:

1.

2.

3.

4.

Makassar,

\section{Observer}

Model instrumen yang dikemukakan di bawah ini, dipergunakan pada observasi yang tanpa menentukan lebih dulu aspek-aspek atau kegiatan-kegiatan serta tingkah laku apa yang akan diamati. ${ }^{18}$ Jadi, observer melakukan pengamatan dan pencatatan tanpa dibatasi oleh kerangka kerja (frame work) yang pasti. Dengan demikian, menurut cara ini, observer dapat mencatat apa saja yang terjadi dalam kegiatan observasi 
tersebut. Dalam hal ini observer dapat memperoleh data yang luas dan bervariasi. Instrumen observasi yang umumnya dipergunakan dalam hubungannya dengan model yang kedua ini berupa skala sikap.

Nama Siswa

Kelas

\begin{tabular}{|r|c|r|r|r|r|}
\hline No. & $\begin{array}{c}\text { Kegiatan/Aspek yang } \\
\text { Dinilai }\end{array}$ & $\begin{array}{c}\text { Sering } \\
\text { Kali }\end{array}$ & $\begin{array}{c}\text { Kadang- } \\
\text { Kadang }\end{array}$ & $\begin{array}{c}\text { Tidak } \\
\text { Pernah }\end{array}$ & Ket. \\
\hline 1. & & & & & \\
2. & & & & & \\
3. & & & & & \\
4. & & & & & \\
6. & & & & & \\
7. & & & & & \\
\hline & & & & & \\
\hline
\end{tabular}

Makassar,

\section{Guru Agama/Penilai}

Ketiga model instrumen observasi yang dipaparkan di atas sangat diperlukan oleh guru-guru di sekolah, untuk memperoleh data tentang siswa, di mana data tersebut tidak mungkin dan sulit diperoleh dengan menggunakan teknik tes. Cara yang pertama dan kedua biasa digunakan dalam penyelidikan-penyelidikan formal (formal studies), sedang cara yang ketiga baik untuk digunakan dalam situasi-situasi informal.

\section{Pencatatan Data Observasi}

Ketika observasi dipergunakan sebagai alat evaluasi dalam dunia pendidikan dan pengajaran, maka pencatatannya pada umumnya jauh lebih sukar dibanding dengan mencatat jawaban-jawaban peserta didik terhadap pertanyaan-pertanyaan dalam suatu tes, atau ujian. Hal tersebut dikarenakan respon yang diperoleh dalam observasi adalah berupa tingkah laku. Pencatatan terhadap tingkah laku bukanlah pekerjaan mudah, evaluator atau observer dituntut untuk dapat mencatatnya dengan cepat dan tepat. Pencatatan terhadap segala sesuatu yang disaksikan dalam 
observasi itu penting sekali karena hal itulah yang akan menjadi landasan untuk menilai makna yang terkandung di balik tingkah laku peserta didik tersebut.

Adapun mengenai cara pencatatan observasi, umumnya menempuh dua cara. Pertama, unit-unit tingkah laku yang akan diamati dirumuskan dan ditentukan terlebih dahulu, dan catatan-catatan yang dibuat hanyalah yang bersangkutan dengan aspek-aspek yang telah ditentukan. ${ }^{19}$ Dengan kata lain, observasi dilakukan dengan berdasar pada kerangka kerja yang memuat faktor-faktor yang telah diatur kategorisasinya. Isi dan luas materinyapun telah ditetapkan dan dibatasi secara tegas, sehingga pengamatan dan pencatatan yang dilakukan oleh evaluator dalam rangka evaluasi hasil belajar peserta didik sifatnya selektif. Observasi yang dilakukan dengan menggunakan pencatatan seperti ini dikenal dengan istilah observasi sistematis. ${ }^{20}$ Faktor-faktor yang tidak terdapat dalam pedoman observasi tidak perlu diamati dan dicatat. Pedoman observasi biasanya berbentuk formulir atau blangko daftar isian yang tersusun, yang didalamnya tercantum gejala-gejala, aspek-aspek atau tingkah laku apa saja yang perlu diamati dan dicatat pada waktu berlangsungnya kegiatan peserta didik.

Kedua, observasi yang dilakukan tanpa menentukan lebih dulu aspek-aspek atau kegiatan-kegiatan serta tingkah laku apa yang akan diamati. ${ }^{21}$ Jadi, observer melakukan pengamatan dan pencatatan tanpa dibatasi oleh kerangka kerja (frame work) yang pasti. Dengan demikian, menurut cara ini, observer dapat mencatat apa saja yang terjadi dalam kegiatan observasi tersebut. Dalam hal ini observer dapat memperoleh data yang luas dan bervariasi. Instrumen observasi yang umumnya dipergunakan dalam hubungannya dengan model yang kedua ini berupa skala sikap.

Masih berkaitan dengan pencatatan kegiatan observasi, sekaligus untuk melengkapi penjelasan kedua cara di atas, dalam membuat catatan, observer atau evaluator harus dapat membedakan hal-hal yang benarbenar merupakan hasil observasi, dan hal-hal yang merupakan tafsiran atau kesan observer. Kedua hal tersebut jangan dicampuradukkan. Pencatatan harus dilakukan dengan cermat dan sistematis dengan kode tertentu untuk tiap topik, kategori dan variabel lalu disimpan terpisah dengan kategori lain, sehingga mempermudah pengolahannya.

\section{Validitas Observasi}

Dalam dunia evaluasi pendidikan dan pengajaran, ada satu hal penting yang harus diperhatikan, yaitu bahwa hasil yang didapat melalui kegiatan evaluasi tersebut harus sesuai dengan keadaan obyek yang 
sebenarnya. Suharsimi Arikunto dalam salah satu tulisannya mengibaratkan kegiatan evaluasi sebagai pekerjaan memotret. Hasil dari kegiatan memotret dikatakan baik jika sesuai dengan aslinya dan bukan lebih baik dari aslinya. Gambar pemotretan hasil evaluasi tersebut di dalam kegiatan evaluasi dikenal dengan data evaluasi. Data evaluasi yang baik yang sesuai dengan kenyataan disebut data valid.

Oleh karena itu, kegiatan observasi hendaknya dilakukan sedemikian rupa sehingga dapat diuji validitas dan reliabilitasnya. Validitas berkenaan dengan ketetapan alat penilaian terhadap obyek yang dinilai sehingga betul-betul menilai apa yang seharusnya dinilai. Dengan demikian, suatu teknik evaluasi dikatakan memiliki validitas tinggi jika ia dapat mengukur apa yang sebenarnya harus diukur.

Dan sebagaimana diketahui bahwa validitas merupakan salah satu syarat terpenting bagi suatu alat penilaian atau evaluasi. Tingkat validitas suatu teknik evaluasi sangat bergantung pada tujuan yang akan diukur atau dinilai. Suatu teknik evaluasi dapat mempunyai validitas yang berbeda-beda jika dipergunakan untuk mengukur tujuan kegiatan belajar yang berlainan.

Teknik observasi, validitasnya sangat tergantung pada kecakapan, pengertian, pengetahuan dan sifat-sifat pengamat itu sendiri. Oleh karena itu, untuk menjaga tetap validnya observasi yang dilakukan, observer atau evaluator hendaknya memperhatikan ketentuan-ketentuan sebagai berikut:

$\Rightarrow$ Seharusnya pencatatan di dalam observasi dilakukan segera dan secepat mungkin, artinya peristiwa yang diamati jangan dibiarkan terlalu lama, sehingga bagian-bagian yang penting tidak terlupakan dan pencatatan dapat lebih objektif.

$\Rightarrow$ Observer atau evaluator harus selalu menyadari bahaya kesalahan interpretasi yang timbul karena kekacauan atau tidak dapat membedakan mana yang berupa gejala dan mana yang berupa sebabsebab.

$\Rightarrow$ Generalisasi dari observasi baru dapat diterima atau dilakukan berdasarkan penelitian yang sangat hati-hati, dan berdasarkan sampel yang luas. Jika tidak demikian, generalisasi dapat merupakan suatu kesimpulan yang keliru dan tidak benar.

$\Rightarrow$ Signifikansi hasil observasi sangat tergantung pada kecakapan, pemahaman dan sifat- sifat pengamat sendiri. ${ }^{22}$

\section{Kelebihan dan Kekurangan Observasi}

Pada bagian akhir tulisan, penulis ingin menegaskan bahwa, penilaian yang dilakukan dengan mempergunakan teknik observasi, tentu saja, 
memiliki beberapa kebaikan, tetapi juga tidak terlepas dari kekurangan.

Di antara kebaikan yang dimiliki oleh observasi adalah:

$\Rightarrow$ Data observasi diperoleh secara langsung dengan mengamati kegiatan atau ekspresi siswa dalam berbuat atau bereaksi terhadap suatu perangsang atau situasi tertentu, sehingga dengan demikian, data yang diperoleh dapat lebih objektif dan melukiskan aspek-aspek kepribadian siswa yang sebenarnya.

$\Rightarrow$ Individu yang diamati tidak merasa on the spot, karena berada dalam situasi yang relatif bebas, dalam situasi yang tanpa tekanan-tekanan dari luar, sehingga dapat melakukan kegiatan dan mengespresikan kebiasaan, minat serta sifat-sifatnya secara spontan.

$\Rightarrow$ Data yang diperoleh melalui observasi mencakup beberapa aspek kepribadian individu sehingga dalam pengolahannya tidak berat sebelah, atau hanya menekankan salah satu segi saja dari kecakapan atau pencapaian hasil belajar siswa. 23

Di samping kebaikan-kebaikan yang disebutkan di atas, observasi juga mengandung beberapa kelemahan sebagai berikut:

$\Rightarrow$ Sebagai suatu teknik evaluasi, observasi memerlukan skill yang baik. Pengamat harus menyadari perbedaan antara tingkah laku yang terlukiskan dengan tingkah laku yang dievaluasi. Dengan bahasa sederhana, pengamat harus dapat membedakan apa-apa yang tersurat dan apa-apa yang tersirat. Pengamat-guru-yang tidak memiliki kecakapan dalam melakukan observasi, hasil observasinya menjadi kurang dapat diyakini kebenarannya.

$\Rightarrow$ Seringkali kepribadian pengamat mewarnai dan menyelinap masuk ke dalam penilaian yang dilakukan dengan observasi. Pengalaman, prasangka, nilai-nilai pengamat/peneliti tidak selalu dapat dipisahkan secara tegas dari tingkah laku siswa yang dicatatnya.

$\Rightarrow$ Tingkah laku yang sama yang diperlihatkan oleh bermacam-macam individu belum tentu mempunyai arti yang sama bagi pengamatpengamat yang lain. Dengan demikian, jika hal itu terjadi, dapat mengurangi objektivitas analisis hasil atau data observasi itu.

$\Rightarrow$ Data yang diperoleh dari observasi tidak dapat memberikan gambaran yang sama tentang struktur kepribadian individu. Artinya, observasi hanya dapat mengungkap "kulit luarnya" saja. Karena itu, observasi harus didukung dengan teknik lain. ${ }^{24}$

\section{PENUTUP}

Observasi adalah pengamatan langsung terhadap tingkah laku peserta didik di dalam situasi sosial, dan merupakan bantuan yang sangat 
penting sebagai suatu alat evaluasi. Namun ada satu hal yang harus selalu diingat ketika menggunakan observasi sebagai alat evaluasi, bahwa pencatatan dan penafsiran hasil observasi pada umumnya jauh lebih sukar daripada mencatat atau memeriksa jawaban-jawaban yang diberikan oleh peserta didik terhadap pertanyaan-pertanyaan yang diberikan dalam suatu tes, ulangan atau ujian, sebab respon yang diperoleh dalam observasi berupa tingkah laku, yang pencatatan dan pemeriksaannya merupakan hal yang sulit, karena itu diperlukan kecakapan pengamat -guru- untuk dapat mencatatnya dengan cermat, sehingga diperoleh hasil pengamatan (baca: penilaian) yang sifatnya valid.

\section{CATATAN AKHIR:}

1. Hampir semua referensi yang membahas Evaluasi pendidikan dan Pengajaran memulai pembahasannya dengan penjelasan tentang perbedaan antara pengukuran, penilaian, adan evaluasi. Kenapa ini dilakukan? Jawabannya adalah karena ketiga kata tersebut sering dipergunakan secara tumpang tindih, dalam artian ketiga kata tersebut sering kali dipergunakan secara bergantian untuk menunjukkan makna yang sama, padahal ketiga kata tersebut memiliki perbedaan. Anas Sudijono dalam bukunya Pengantar Evaluasi Pendidikan menjelaskan bahwa, pengukuran berarti kegiatan yang dilakukan untuk "mengukur" sesuatu. Mengukur berarti membandingkan sesuatu dengan dasar ukuran tertentu. Sebagai contoh, Ali menjawab betul 9 nomor dari 10 soal yang dikeluarkan dalam satu kesempatan tes. Dengan demikian pengukuran sifatnya kuantitatif. Penilaian berarti menilai sesuatu. Menilai mengandung arti mengambil keputusan terhadap sesuatu dengan dengan berpegang pada ukuran tertentu. Berdasarkan contoh di atas, dapat dipahami bahwa si Ali termasuk anak yang pandai. Dengan demikian penilaian sifatnya kualitatif. Sedangkan evaluasi mencakup pengukuran dan penilaian. Evaluasi adalah kegiatan untuk menilai sesuatu, untuk dapat menentukan nilai dari sesuatu perlu dilakukan pengukuran. Penjelasan lebih jauh, baca, Anas Sudijono, Pengantar Evaluasi Pendidikan, (Jakarta: PT RajaGrafindo Persada, 2001), h. 3-7

2. W. A. Mehrens dan I. J. Lehmann, Measurement and Evaluation in Education and Psychology, (New York: Rinehart and Winston, 1978), h. 5

3. Norman E. Gronlund, Measurement and Evaluation in Teaching, (New York: Collier Macmillan Publisher, 1976), h. 10

4. Wrightstone et. Al. Evaluation in Modern Education, (New York: American Book Company, 1956), h. 16

5. Nasution, Metode Research, (Jakarta: Bumi Aksara, 2000), h. 106.

6. Nasution, Metode Research, h. 107. Lihat juga, Anas Sudijono, Pengantar Evaluasi Pendidikan, (Jakarta: PT RajaGrafindo Persada, 2001), h. 77

7. Wayan Nurkencana \& P. P. N. Sunarta, Evaluasi Pendidikan, (Surabaya: Usaha Nasional, 1986), h. 47.

8. Nasution, Metode Research, h. 85.

9. Nasution, Metode Research, h. 85

OBSERVASI SEBAGAI ALAT EVALUASI (SITTI MANIA) 
10. Contoh kongkrit tentang kesulitan tersebut ialah apabila seorang peneliti hendak mempelajari kehidupan gelandangan atau germo, maka dapat dibayangkan betapa sukarnya dapat diterima menjadi salah seorang di antara mereka. Keterangan lebih lanjut, lihat, Nasution, Metode Research, h. 107-108.

11. Ngalim Purwanto, Prinsip-prinsip dan Teknik Evaluasi Pengajaran, (Bandung: Remaja Rosdakarya, 1994), h. 150.

12. Ngalim Purwanto, Prinsip-prinsip dan Teknik Evaluasi Pengajaran, h. 150.

13. Anas Sudijono, Pengantar Evaluasi Pendidikan, h. 77

14. Ngalim Purwanto, Prinsip-prinsip dan Teknik Evaluasi Pengajaran, (Bandung: Remaja Rosdakarya, 1994), h. 150.

15. Anas Sudijono, Pengantar Evaluasi Pendidikan, 76.

16. Nana Sudjana, Penilaian Hasil Proses Belajar Mengajar, (Bandung: PT. Remaja Rosdakarya, 1995), h. 85-86.

17. Anecdotal record ialah suatu deskripsi faktual tentang perilaku yang bermakna dan peristiwa yang dialami seseorang yang diamati dan dicatat oleh observer. Keterangan lebih lanjut lihat, Idrus Abustam dkk., Pedoman Praktis Penelitian dan Penulisan Karya Ilmiah, (Makassar: Lembaga Penelitian Universitas Negeri Makassar, 1996), 74.

18. Ngalim Purwanto, Prinsip-prinsip dan Teknik Evaluasi Pengajaran, h. 151

19. Ngalim Purwanto, Prinsip-prinsip dan Teknik Evaluasi Pengajaran, h. 151.

20. Anas Sudijono, Pengantar Evaluasi Pendidikan ,h. 78.

21. Ngalim Purwanto, Prinsip-prinsip dan Teknik Evaluasi Pengajaran, h. 151

22. Ngalim Purwanto, Prinsip-prinsip dan Teknik Evaluasi Pengajaran, h. 152.

23. Ngalim Purwanto, Prinsip-prinsip dan Teknik Evaluasi Pengajaran, h. 153.

24. Ngalim Purwanto, Prinsip-prinsip dan Teknik Evaluasi Pengajaran, h. 154. Baca juga, Anas Sudijono, Pengantar Evaluasi Pendidikan, h. 81-82.

\section{DAFTAR PUSTAKA:}

Abdullah, M. Amin, Studi Agama: Normativitas atau Historisitas?, cet. I, Yogyakarta: Pustaka Pelajar, 1996.

Abustam, Idrus. dkk., Pedoman Praktis Penelitian dan Penulisan Karya Tulis Ilmiah, Makassar: Lembaga Penelitian Universitas Negeri Makassar, 1996.

Arikunto, Suharsimi. Dasar-dasar Evaluasi Pendidikan, Jakarta: Bumi Aksara, 1997.

Gronlund, Norman E. Measurement and Evaluation in Teaching, New York: Collier Macmillan Publisher, 1976.

Hantoro, Budi. Evaluasi Pendidikan dan Metodologi, http: // www. Infogue. Com.

Koentjaraningrat, Metode-metode Penelitian Masyarakat, Jakarta: PT. Gramedia, 1981.

Mehrens, W. A. dan I. J. Lehmann, Measurement and Evaluation in Education and Psychology, New York: Rinehart and Winston, 1978.

Nasution, Metode Research, Jakarta: Bumi Aksara, 2000.

Nitko, A. J. Educational Test and Measurement, an Introduction, New York: Harcourt Brace Javanovich, Inc.

Nurkencana, Wayan dan P. P. N. Sunarta, Evaluasi Pendidikan, Surabaya: Usaha Nasional, 1986. 
Purwanto, Ngalim. Prinsip-prinsip dan Teknik Evaluasi Pengajaran, Bandung: PT. Remaja Rosdakarya, 1994.

Sudijono, Anas. Pengantar Evaluasi Pendidikan, Jakarta: PT. RajaGrafindo Persada, 2001.

Singarimbun, Masri dan Sofian Effendi, Metode Penelitian Survai, Jakarta: PT. Pustaka LP3ES Indonesia, 1989.

Sudjana, Nana. Penilaian Hasil Proses Belajar Mengajar, Bandung: PT. Remaja Rosdakarya, 1995.

Wrightstone et. Al. Evaluation in Modern Education, New York: American Book Company, 1956.

Yin, Robert K. Studi Kasus (Desain dan Metode), Jakarta: PT. RajaGrafindo Persada, 2000. 